\title{
The Impact of Organizational Culture and Work Motivation on Employee Performance through Employee Satisfaction of Air Mas Perkasa
}

\author{
Basuki Surodjo ${ }^{1}$, Pudji Astuty ${ }^{2}$ \\ \{basuki_surodjo@gmail.com¹,Pudji_astuty@borobudur.ac.id² $\}$ \\ Universitas Borobudur, Jakarta, Indonesia ${ }^{1,2}$
}

\begin{abstract}
The goal of this study is to look at the direct and indirect effects of organizational culture and job motivation on employee performance. A total of 120 employees were sampled. The company culture has an impact on employee performance, as according data analysis approaches employing SEM. Employee motivation has a positive impact on their performance. Employee job satisfaction is positively influenced by organizational culture. Employee work satisfaction has a favorable correlation with work motivation. Job satisfaction has a favorable impact on Air Mas Perkasa's staff performance. The corporation should always maintain and harmonize the function of organizational culture in the life of corporate activities, focusing on the company's interests and objectives in order to increase employee performance and be sensitive to factors that can improve work motivation.
\end{abstract}

Keywords: Organizational Culture; Work Motivation; Job Satisfaction; Employee Performance

\section{Introduction}

Companies must function more effectively and efficiently in order to compete in the global era. Companies must be able to increase their competitiveness in order to stay afloat in the face of ever-increasing competition. Air Mas Perkasa is one of Indonesia's technology businesses with a policy of maximizing employee productivity in order to carry out the company's business procedures. Employees are the most crucial factor in determining a company's success. Employees who are in compliance with the company's objectives and demands, and who are capable of carrying out the tasks that have been set by the company, are required to realize the firm's goals. In general, every firm will strive to increase its employees' performance in the hopes of achieving the company's objectives.

Employees' abilities are represented in their performance, and good performance is the best performance. Employee performance is one of the most important factors in a company's ability to fulfill its objectives. As a result, company executives should take employee performance into account. Performance is described as a person's ability to do a task successfully. Employee performance is the outcome of a person's efforts in carrying out the tasks allocated to him in order to meet work objectives. Employees that have a high level of 
motivation can do well at work. so that they can deliver the best work possible Employee performance is one of the defining variables in a company's or organization's ability to achieve its objectives. The level of achievement of the results of "the degree of accomplishment" in the organization is described as performance or the level of achievement of organizational goals on a continuous basis [1]. Organizational performance is a metric that measures how well tasks are carried out and the organization's objective is accomplished [2]. As a result, employee performance must be brought to the attention of company management, because poor employee performance can influence company or overall organizational performance.

Another factor that can affect employee performance is Job satisfaction among employees. Employment satisfaction refers to an individual's overall attitude toward his or her job; a person who is content with his or her job has a good attitude toward it, whereas a person who is unsatisfied with his or her job has a negative attitude toward it [3]. In line with this, according to Umam said that Work satisfaction is a good attitude toward one's job that arises from an assessment of one's work circumstances [4]. Evaluation is carried out as a sign of gratitude for accomplishing one of his work's most significant values. Employees that are happy with their jobs prefer them to others dissatisfied employees, who do not like their work situations.

Organizational culture refers to abstractions such as values and conventions that cover the entire or part of a firm. This may go unnoticed, undefined, and undiscussed. However, a person's behavior at work might be influenced by their culture. Every company needs organizational culture, which must be constantly developed and adapted to changes in the business environment. Human resources from various backgrounds and levels make up the organizational environment. As a result, changes in organizational culture begin with a shift in the thinking of all human resources inside the organization.

Work Motivation is the providing of a driving force that inspires people to desire to collaborate, work efficiently, and be fully integrated in their attempts to achieve satisfaction [5]. Work motivation is an urge to work in order to achieve goals or satisfaction. Employee work motivation is when employee motivation decreases, it is vital to make attempts to increase job motivation. Paying attention to and satisfying the needs of employees, as well as praising the results of their labor, can help to boost employee motivation.

\subsection{Research Problem Formulation}

The formulation of the research problem is as follows:

a. Does Does Airmas Group employee performance have a direct impact on organizational culture?

b. Does Workplace motivation has a direct impact on productivity of Airmas Group employees?

c. Does Organizational Culture have a direct effect on Job Satisfaction of Airmas Group employees?

d. Does work motivation directly affect the job satisfaction of Airmas Group employees?

e. Does Organizational Culture have an indirect effect on Airmas Group Employee Performance?

f. Does work motivation have an indirect effect on the performance of Airmas Group employees?

g. Does Job Satisfaction Directly Affect Airmas Group Employee Performance? 


\subsection{Hypothesis}

Based on the theoretical description and framework of thinking above, in this study the following hypothesis is proposed:

H1 = Organizational Culture has a direct effect on Employee Performance

$\mathrm{H} 2=$ Work Motivation has a direct effect on Employee Performance

H3 = Organizational Culture has a direct effect on Job Satisfaction

H4 = Work Motivation has a direct effect on Job Satisfaction

H5 = Organizational Culture has an indirect effect on Employee Performance

H6 = Work Motivation has an indirect effect on Employee Performance

H7 = Job Satisfaction has a direct effect on Employee Performance

\section{Methodology}

Descriptive statistics are statistics that describe phenomena or characteristics of the data [6]. The characteristics of the data described are the characteristics of their distribution. Data analysis in this study used the structural equation modeling (SEM) method. SEM or structural equation modeling is a multivariate technique that integrates numerous components, such as factor analysis and multiple regression, to allow researchers to examine a series of dependence relationships between measured and latent variables concurrently (simultaneously) as between several latent variables [7]. Researchers used SEM in this study because the model tested in this study had many relationships between latent variables simultaneously. Cooper and Schindler, state that SEM can explain measurement errors in the estimation process that regression cannot explain [8]. Hair et al., states that there are three kinds of strategies that can be used in SEM [7].

This study uses a confirmatory modeling strategy. The use of SEM by applying a confirmatory modeling strategy focuses on analyzing and measuring the suitability of the model or model fit of the model used in this study with the reality represented by the data that has been collected [7]. The research was conducted for 3 months, 1 month for instrument testing, dissemination, and field research data collection, 2 months for report preparation data. This research was conducted at Airmas Group having its address at Kyai Haji Zainul Arifin street, Ketapang Indah Complex Block B3 No. 8-9, West Jakarta for management office and warehouse location in the Sunter area, North Jakarta, the research started from October 2019 to January 2020.

\section{Results and Discussion}

\subsection{Hypothesis Testing}

The hypothesis test is stated that $\mathrm{H} 0$ is rejected or the variable has an effect if the $\mathrm{t}$-value> 1.96 at $=0.05$.

a. The influence of Organizational Culture on Employee Performance. The t-value result is 6.81, as can be seen. According to the findings of the hypothesis test at the 95 percent confidence level using the t-value $>1.96, \mathrm{H} 01$ is rejected because its t-value is 6.81 . According to the rejection of H01, organizational culture has a substantial impact on employee performance. This proves that the study's purpose of identifying the impact of 
organizational culture on employee performance was met performance in the Airmas Group environment was met.

b. The Influence of The Effects of Workplace Motivation on Employee Performance the tvalue result is 6.04 , as can be seen. $\mathrm{H} 02$ is rejected since its t-value is 6.04 , according to the findings of the hypothesis test at the 95 percent. The t-value $>1.96$ was used to calculate the confidence level. H02 is rejected because it claims that job motivation has a significant impact on employee performance. This demonstrates that the research goal of determining the impact of job motivation on employee performance was met in the Airmas Group work environment is proven.

c. The Influence of Organizational Culture on Job Satisfaction. The t-value result is 7.57, as can be seen. According to the outcomes of the hypothesis test at the 95 percent confidence level when considering the $\mathrm{t}$-value $>1.96, \mathrm{H} 03$ is rejected because the t-value is 7.57 . H03 is rejected because it claims that company culture has a significant impact on job satisfaction. This shows that the study's goal of determining the impact of corporate culture on work satisfaction was met was met in the Airmas Group work environment is proven.

d. The Effect of Work Motivation on Job Satisfaction. The t-value result is 5.46, as can be seen. H04 is rejected since the t-value is 5.46, according to the findings of the hypothesis test at the 95 percent confidence level when considering the $t$-value $>1.96$. The rejection of $\mathrm{H} 04$ asserts that work motivation has a major impact on job satisfaction. This demonstrates that the research goal of determining the impact of work motivation on job satisfaction in the Airmas Group work environment is proven.

e. The Effect of Job Satisfaction on Employee Performance. It The t-value result is 7.08, as can be seen. H05 is rejected since the t-value is 7.08, according to the findings of the hypothesis test at the 95 percent When the t-value is greater than 1.96, the confidence level is higher. H05 is rejected because it claims that job satisfaction has a significant impact on employee performance. This shows that the study's purpose of determining the impact of work satisfaction on employee performance was met was met in the Airmas Group work environment is proven.

f. Direct and Indirect Effect, $\xi 1, \xi 2, \eta 1$ and $\eta 2$ and Total Effects. This research can see the direct and indirect effects. The direct effect is the effect that occurs between 2 latent variables when an arrow connects the two, while the indirect effect is the effect that occurs between 2 latent variables, there is no direct arrow between the two variables but through one or more other latent variables according to the existing trajectory. Based on the data, the most influential variable on Employee Performance is Organizational Culture.

\subsection{Discussion}

\subsubsection{The Direct Effect of Organizational Culture on Airmas Group Employee Performance}

This indicator is obtained based on the results of research through a field study of questionnaire distribution, where the perceptions of the respondents studied indicate that there is a good culture in the company, this result is evidenced by statistical tests where the beta coefficient value is 0.57 or almost $57 \%$ Organizational Culture has an effect on Employee Performance. Likewise, from the results of hypothesis testing where the t-count value is 6.81 or greater than the t-table value of $1.960(n=120,=5 \%)$. Indicators of the existence of this good relationship can also be seen in several indicator variables, especially from the aspects of values, morality, norms and ethics, and how to communicate in serving customers is an 
important part of the organizational culture of the company. Although it is undeniable that there are some things that are lacking, such as patterns of behavior and ways of working that are still poorly patterned so that they are not optimal for performance.

The results of this study are relevant to several previous research results, such as those of H.M. Affandi (2002), in his research entitled "The Influence of Organizational Climate on Job Satisfaction, Commitment and Employee Performance in the Semarang City Government". It is concluded that Organizational Climate affects job satisfaction and Organizational Climate affects Employee Performance [9]. Likewise, research conducted by Ahim Surachim and Taofik Firdaus (2008), concerning: The Effect of Organizational Climate on Employee Job Satisfaction at PT. Combiphar's Parmaservise Division, Jakarta, who found that organizational climate had a beneficial impact on employee job satisfaction [10].

\subsubsection{The Direct Effect of Work Motivation on the Performance of Airmas Group Employees}

From the results of statistical tests At Airmas Group, work motivation has a favorable impact on staff performance. This indicator is derived through statistical tests, and the beta coefficient value obtained a value of 0.47 , indicating that work motivation influences nearly $47 \%$ of employee performance. Likewise, from the results of hypothesis testing, the t-count value is 6.04 or greater than the t-table value of $1.960(n=120,=5 \%)$. Of the several indicator variables studied that play a role in the existence of work motivation for employees such as rank, career or position, work procedures, social status, freedom in carrying out work, and desired achievements. However, there are some indicators that are less influential, such as lack of competence in tasks, and assessment of work.

The existence of a Workplace motivation and employee performance have a positive association the definition as stated by G.R. Terry quoted by Hasibuan (2006) that "motivation is the desire contained in an individual who stimulates him to take actions" [11]. Thus, motivation can be likened to the driving force or a driving force that inspires a person's activity or work to function ideally, both individually and collaboratively, to work efficiently, and to be integrated into all of his efforts to achieve what he wants.

\subsubsection{The Direct Effect of Organizational Culture on Job Satisfaction of Airmas Group Employees}

From the results of statistical tests there is a positive influence of Organizational Culture on Job Satisfaction at Airmas Group. This indicator is obtained based on the results of statistical tests, from the beta coefficient value obtained a value of 0.59 or almost $59 \%$ Job Satisfaction is influenced by Organizational Culture, this is reinforced from the results of hypothesis testing, the $t$-count value is 7.57 or greater than the $t$-table value of $1.960(n=120$, $=5 \%$ ).

Indicators of this good relationship can be seen from several indicator variables, especially from indicators of satisfaction variables, attitudes at work, interactions between employees and superiors or between employees and other employees, and encouragement to excel. This shows that job satisfaction is also not solely due to the influence of the amount of salary or benefits, but also because of the influence of organizational culture within the company. This organizational culture is related to the behaviors that occur within the company, how each employee acts, thinks and feels in an organization. This is in line with the opinion of Wirawan (2007), Organizational culture refers to the norms, values, assumptions, beliefs, philosophies, 
organizational habits, and so on that have been developed over time by the organization's founders, leaders, and members and are socialized and taught to new members as well as applied in organizational activities to influence members' mindsets, attitudes, and behavior of the organization in producing items, providing customer service, and attaining organizational objectives [12]. Because of the high level of unity and intensity required to build an internal climate, it is apparent that a successful corporate culture will have a significant impact on the conduct of its members. If the culture is bad, the level of unity and energy needed to establish a positive organizational climate will be reduced. Organizational culture can also boost productivity. Where a positive organizational culture fosters employee motivation, job satisfaction, and work ethic. All of these elements point to the development of high personnel performance, which leads to good organizational performance.

\subsubsection{The Direct Effect of Work Motivation on Job Satisfaction of Airmas Group Employees}

Based on the results of statistical tests, Work motivation has a positive effect on staff job satisfaction at Airmas Group. This indicator is obtained based on the results of statistical tests, from the beta coefficient value obtained a value of 0.49 or almost $49 \%$ Job Satisfaction is influenced by Work Motivation, this is reinforced from the results of hypothesis testing where the $\mathrm{t}$-count value is 5.46 or greater than the $\mathrm{t}$-table value of $1.960(\mathrm{df}=\mathrm{n}-2,120-2=118,=5 \%)$.

Indicators of this good relationship can be seen from several indicator variables, especially from the indicators of satisfaction variables, attitudes at work, the influence of the amount of salary/benefits, social security, and facilities provided by the company. This is in line with the opinion of Hasibuan (2003) which states that "A person tends to work with enthusiasm if satisfaction can be obtained from his work and employee job satisfaction is the key to driving morale, discipline, and employee performance in supporting the realization of company goals" [13]. Likewise, the opinion of Wirawan (2015) which states that job satisfaction is the perception of people's feelings and attitudes regarding various aspects of their work [14].

\subsubsection{Indirect Influence of Organizational Culture on Airmas Group Employee Performance}

The test results show that work satisfaction has a 0.30 indirect effect on employee performance because of organizational culture $(30$ percent). This indicates that the Work Culture has been well-formed, resulting in higher employee job satisfaction, which has an impact on Airmas Group employees' performance.

\subsubsection{Indirect Effect of Work Motivation on Airmas Group Employee Performance}

Work motivation has a 0.25 indirect effect on employee performance, according to the results of the tests through job satisfaction ( 25 percent). This means that an employee's work motivation leads to increased job satisfaction, which in turn leads to improved Airmas Group employee performance. 


\subsubsection{The Direct Effect of Job Satisfaction on the Performance of Airmas Group employees}

Based on the results of statistical tests Job satisfaction has a positive effect on employee performance at Airmas Group. This indicator is obtained based on the results of statistical tests, from the beta coefficient value obtained a value of 0.51 or almost $51 \%$ Employee Performance is influenced by Job Satisfaction, this is reinforced from the results of hypothesis testing where the $t$-count value is 7.08 or greater than the $t$-table value of $1.960(\mathrm{df}=\mathrm{n}-2,120-2=118,=5 \%)$.

Indicators of this significant influence can be seen in several indicator variables, especially from employee performance such as work achievement, work quality, work initiative, although there are several indicator variables that are less significant. The better the level of employee satisfaction, the employee's performance will also increase, on the contrary if the level of satisfaction decreases, the employee's performance will automatically decrease. Therefore, job satisfaction is an important aspect in the company. In fact, many company leaders are not fully aware of the influence and importance of job satisfaction.

\section{Conclusion and Suggestion}

\subsection{Conclusion}

After testing and analyzing the data to test the proposed research hypotheses, several conclusions were obtained as follows:

a. Based on the results of data processing on the The effect of the Organizational Culture variable on Job satisfaction has a positive effect on employee performance.

b. Based on the work's data processing results The motivation variable has a significant impact on employee performance 0.47 percent. This suggests that work motivation has a beneficial impact on Airmas Group employees' performance.

c. 3. The influence of the Organizational Culture variable on Job Satisfaction is 0.59 or 59 percent, according to the results of data processing. This suggests that organizational culture has a favorable impact on Airmas Group employees' job satisfaction..

d. Based on The effect of data processing on the work motivation variable on job satisfaction is 0.49 percent or $49 \%$. This means that work motivation has a positive influence on job satisfaction of Airmas Group employees

e. The test The results show that organizational culture has an indirect impact on employee performance through job satisfaction. is equal to 0.30 (30 percent). This indicates that the Work Culture has been well-formed, resulting in increased employee job satisfaction, which has an impact on Airmas Group employees' performance.

f. The test results show that there is an Work motivation has a 0.25 Job satisfaction has an indirect effect on employee performance ( 25 percent). This suggests that higher employee work motivation leads to increased employee job satisfaction, which is a positive idea impact on the Airmas Group's employees' performance

g. The influence of the Employee Performance is influenced by Job Satisfaction 0.51 percent, according to the results of data processing. This suggests that job happiness has a beneficial impact on Airmas Group employees' performance. 


\subsection{Suggestion}

Based on the discussion and conclusions that have been stated previously, the suggestions from this research are:

a. The Company talways maintains and harmonizes the role of organizational culture in dayto-day operations of the company, concentrating on the company's objectives and goals in order to improve employee performance Some things that need to be done to further optimize organizational culture are as follows:

1. Developing an Organizational Culture, especially a learning culture and a culture of innovation to answer the challenges of the insurance world in the future

2. Complementing the behavior of a good service culture with behavioral patterns of introducing and marketing the company's products. This pattern of behavior must be imprinted on all company employees.

3. The work ethic of employees is further enhanced by sticking to the spirit of hard work, smart work, thorough work and sincere work.

b. Companies tmust be aware of factors that can boost work motivation. Work motivation that is directed, clear and structured which is always oriented to the interests and aims of the company is expected to increase employee performance. A few things to do:

1. The active role of the leader is to motivate employees in carrying out their daily tasks.

2. Evaluate and improve the company's provisions so that they do not overlap, especially those regarding provisions regarding organizational work systems and procedures, provisions regarding human resources

c. Increasing Employee Job Satisfaction will have an impact on improving employee performance. Some things the Company can do:

1. Always create a conducive work climate

2. Assessing and assessing the requirement for suitable work facilities and equipment. infrastructure and adapted to the company's capabilities.

3. Evaluate and analyze the compensation provided according to the needs and capabilities of the company.

\section{References}

[1] Keban, Y. T. Enam Dimensi Strategis Administrasi Publik, Konsep, Teori dan Isu. Yogyakarta: Gava Media. (2004).

[2] Steers, R. \& Porter, L. W,. Motivation and Work Behavior. New York: Mc Graw-Hill Book Company. (2003)

[3] Robbins, S. P. "Prinsip-Prinsip Perilaku Organisasi”. Jakarta: Erlangga. (2002).

[4] Umam, K., Perilaku Organisasi. Bandung: Pustaka Setia. (2010).

[5] Hasibuan, M. S. P., Manajemen Sumber Daya Manusia. Revisi ed. Jakarta: Bumi Aksara. (2014).

[6] Hartono. "Analisis Item Instrumen [Instrument Item Analysis]". Pekanbaru: Zanafa Publishing bekerja sama dengan Musa Media Bandung (2010)

[7] F. Hair Jr, J., Sarstedt, M., Hopkins, L. and G. Kuppelwieser, V. "Partial least squares structural equation modeling (PLS-SEM): An emerging tool in business research", European Business Review, Vol. 26 No. 2. (2014) 
[8] Cooper, Donald R., dan Pamela S. Schindler., "Bussiners Research Method." New York: McGrawHill (2018)

[9] Affandi., H.M. "Pengaruh Iklim Organisasi Terhadap Kepuasan Kerja, Komitmen dan Kinerja Pegawai di Pemerintah Kota Semarang [The Influence of Organizational Climate on Job Satisfaction, Commitment and Employee Performance in the Semarang City Government]". Universitas Diponegoro Semarang. (2002)

[10] Surachim, Ahim. "PENGARUH IKLIM ORGANISASI TERHADAP KEPUASAN KERJA KARYAWAN PADA DIVISI PHARMASERVE DI PT COMBIPHAR JAKARTA [The Effect of Organizational Climate on Job Satisfaction of Employees at the Parmaservise Division of PT. Combiphar, Jakarta]'. Strategic: Jurnal Pendidikan Manajemen Bisnis. (2008). Doi:8. 58. 10.17509/strategic.v8i1.1005.

[11] Hasibuan, M. S. P. "Manajemen Sumber Daya Manusia [Human Resources Management]". Revisi ed. Jakarta: Bumi Aksara. (2006)

[12] Wirawan, (2007). Budaya dan Iklim Organisasi [Organizational Culture and Climate]. Jakarta: Salemba Empat.

[13] Hasibuan, M. S. "Manajemen Sumber Daya Manusia [Human Resources Management]". Revisi ed. Jakarta: Bumi Aksara. (2003)

[14] Wirawan. "Manajemen Sumber Daya Manusia Indonesia: Teori, Psikologi, Hukum Ketenagakerjaan, Aplikasi dan Penelitian: Aplikasi dalam Organisasi Bisnis, Pemerintahan dan Pendidikan.”. Jakarta: Rajawali Pers. (2015) 